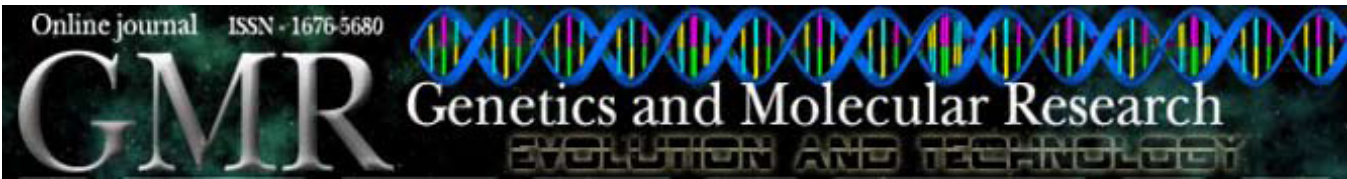

\title{
SSR-based molecular analysis of economically important Turkish apricot cultivars
}

\author{
A.E. Akpınar ${ }^{1}$, H. Koçal' ${ }^{2}$ A. Ergül ${ }^{1}$, K. $\operatorname{Kazan}^{3}$, M.E. Şelli ${ }^{1}$, M. Bakır ${ }^{1}$, \\ Ş. Aslantaş ${ }^{1}$, S. Kaymak ${ }^{2}$ and R. Sarıbaş² \\ ${ }^{1}$ Ankara University, Biotechnology Institute, Ankara, Turkey \\ ${ }^{2}$ Ministry of Agriculture and Rural Affairs, \\ Horticultural Research Institute, Egirdir, Isparta, Turkey \\ ${ }^{3}$ Commonwealth Scientific and Industrial Research Organization Plant Industry, \\ Queensland Bioscience Precinct, St. Lucia, Queensland, Australia \\ Corresponding author: A. Ergül \\ E-mail: ergul@agri.ankara.edu.tr; aliergul2001@yahoo.com
}

Genet. Mol. Res. 9 (1): 324-332 (2010)

Received October 30, 2009

Accepted November 27, 2009

Published February 23, 2010

\begin{abstract}
Turkey is not only the main apricot (Prunus armeniaca) producer and exporter in the world, but it also has a wide variety of apricot germplasms, owing to its close proximity to the centers of apricot origin. However, there is little or no genetic information on many apricot cultivars that are extensively cultivated in Turkey. We examined the genetic relatedness of 25 Turkish and four exotic apricot cultivars using SSR (simple sequence repeat) markers that were either previously developed for apricot, or for peach (P. persica), a close relative of apricot. Allele diversity (with an average allele number of 6.37) at the SSR loci and the heterozygosity rates (with an average Ho value of 0.648 ) of these cultivars were found to be higher than in previous studies that used the same loci for apricot. This fact might be attributed to the analysis of different numbers of accessions in the different studies. No correlations were found between the genetic relatedness and the geographical distributions of these cultivars. The data reported here will assist in the prevention of confusions in the apricot propagation and breeding in Turkey. The findings can also be directly compared with other studies that used the same SSR markers on apricot.
\end{abstract}

Key words: Apricot; Simple sequence repeats; Turkey 


\section{INTRODUCTION}

Apricot (Prunus armenica L.), a fruit species of the family Rosaceae, genus Prunus L., is widely distributed in the Mediterranean region and the Middle East, as well as Armenia, India, Pakistan, China, and Japan. Apricots have also been taken to the New World by settlers and are now grown mainly in California (Hormaza et al., 2007).

Apricots are consumed as fresh fruit, canned, or frozen, but a large portion of the worldwide apricot production is preserved primarily by drying. Turkey is the top apricot-producing country in the world (http://en.wikipedia.org/wiki/Apricot). It accounts for about 12\% (579,000 tons) of world's annual apricot production (Anonymous, 2003). Apart from the Black Sea region and some parts of Eastern Turkey, apricots are widely cultivated in many parts of the country. In the East Anatolia region, apricots are mainly grown to produce dried fruits. Fresh fruit production from apricots mainly occurs in the Marmara (Thrace) region, while apricots are grown for both fresh and dried fruit production in Central Anatolia. Precocious fruits of apricot from the Mediterranean and Aegean regions of Turkey are also consumed freshly in early spring (Asma et al., 2007). The Malatya province located in East Anatolia with diverse apricot germplasm is the center of apricot production, and this region alone provides nearly $50 \%$ of all apricot production in Turkey (Anonymous, 2003).

Although Turkey is not the center of origin for apricots, its unique location on the historic Silk Road between Armenia (the center of apricot origin) and the Europe has probably contributed to the formation of a rich genetic diversity of apricots in Turkey (Özbek, 1978). The climatic suitability of this region for apricot production, combined with social and economic factors, has further diversified apricot production. Some of the world's most famous apricot genotypes for dried (e.g., cvs. HacıHaliloğlu, Kabaaşı, Çataloğlu) and fresh (e.g., cvs. Hasanbey, Alyanak, Şekerpare) fruit production are widely cultivated in the region (Hormaza et al., 2007).

Although apricots are important agricultural export commodities for the Turkish economy, the genetic relatedness of current apricot cultivars grown in the country is largely unknown. This information would greatly assist in the identification, breeding and germplasm preservation of Turkish apricots.

Molecular markers, which show independence from the developmental stage and environmental factors, provide highly discriminatory information and, therefore, are frequently used for genetic studies. Randomly amplified polymorphic DNAs (Badenes et al., 1998; Mariniello et al., 2002), amplified fragment length polymorphisms (Hagen et al., 2002; Hurtado et al., 2002; Geuna et al., 2003), and simple sequence repeats (SSRs) (Hormaza, 2002; Zhebentyayeva et al., 2003; Sánchez-Pérez et al., 2005; Maghuly et al., 2005; Pedryc et al., 2009) have been previously used for apricots. However, to the best of our knowledge, no reports have so far been published on genetic characterization of Turkish apricot genotypes.

In this study, 29 economically important apricot genotypes that included 25 genotypes native to Turkey as well as four exotic cultivars were genetically characterized using eight SSR loci. The allele sizes generated by these markers for each cultivar and the genetic relationships among cultivars were determined. The correlation between genetic relatedness of Turkish apricot cultivars and their geographical distributions is also discussed. 


\section{MATERIAL AND METHODS}

\section{Plant material}

The apricot cultivars used in this study were obtained from Horticultural Research Institute, Egirdir, Isparta, Turkey. A list of these cultivars as well as several of their pomological and phenological characteristics are presented in Table 1. Of the exotic apricot genotypes used, Feriana and Beliana were derived from a cross between Hamidi, a Tunisian apricot cultivar, and Canino, a Spanish apricot cultivar, also included in our experiments (Batmaz, 2005). A fourth exotic apricot genotype studied here is Fracasso, an Italian apricot cultivar with unknown descent.

\begin{tabular}{|c|c|c|c|c|c|c|c|c|c|c|c|c|c|c|}
\hline \multirow[t]{2}{*}{ No. } & \multirow{2}{*}{$\begin{array}{c}\text { Cultivar } \\
\text { name }\end{array}$} & \multicolumn{4}{|c|}{ Phenology } & \multicolumn{8}{|c|}{ Pomology } & \multirow{2}{*}{$\begin{array}{l}\text { Origin } \\
\text { (city) }\end{array}$} \\
\hline & & $\begin{array}{c}\text { Bud } \\
\text { bursting }\end{array}$ & $\begin{array}{c}\text { First } \\
\text { blooming }\end{array}$ & $\begin{array}{c}\text { Full } \\
\text { blooming }\end{array}$ & Ripening & $\begin{array}{l}\text { Fruit } \\
\text { shape }\end{array}$ & $\begin{array}{l}\text { Fruit } \\
\text { taste }\end{array}$ & $\begin{array}{c}\text { Pit } \\
\text { shape }\end{array}$ & $\begin{array}{l}\text { Kernel } \\
\text { flavor }\end{array}$ & $\begin{array}{c}\text { Pit } \\
\text { separation }\end{array}$ & $\begin{array}{l}\text { Skin } \\
\text { color }\end{array}$ & $\begin{array}{l}\text { Fruit } \\
\text { firmness }\end{array}$ & Usage & \\
\hline 1 & Alyanak & $17-30 \mathrm{M}$ & $30 \mathrm{M}-3 \mathrm{~A}$ & $3-10 \mathrm{~A}$ & 15-19Jy & Ovate & Sourish & Ovate & Bitter & Free & Orange & Soft & $\mathrm{F}$ & İzmir \\
\hline 2 & Çekirge-52 & $21-31 \mathrm{M}$ & $30 \mathrm{M}-3 \mathrm{~A}$ & $3-9 \mathrm{~A}$ & $13 \mathrm{Jy}$ & Ovate & Sweet & Round & Sweet & Semi-Joint & Orange & Soft & $\mathrm{F}$ & Bursa \\
\hline 3 & Çöloğlu & $27-29 \mathrm{M}$ & $2-4 \mathrm{~A}$ & $8-10 \mathrm{~A}$ & $12 \mathrm{Jy}$ & Round & Sweet & Round & Sweet & Free & Yellow & Soft & F-D & Malatya \\
\hline 4 & Çataloğlu & $29 \mathrm{M}-2 \mathrm{~A}$ & $29 \mathrm{M}-2 \mathrm{~A}$ & 6-8A & 15Jy & Ovate & Sweet & Ovate & Sweet & Free & Yellow & Good & & Malatya \\
\hline 5 & Ethembey & $22-30 \mathrm{M}$ & $27 \mathrm{M}-3 \mathrm{~A}$ & $31 \mathrm{M}-10 \mathrm{~A}$ & 13Jy & Oblong & Sweet & Ovate & Bitter & Free & Yellow & Soft & F & Edirne \\
\hline 6 & Hacı Haliloğlu & $29 \mathrm{M}-2 \mathrm{~A}$ & $8-10 \mathrm{~A}$ & $12-14 \mathrm{~A}$ & 13-15Jy & Ovate & Sweet & Ovate & Sweet & Free & Yellow & Good & D & Malatya \\
\hline 7 & Hackkzz & $31 \mathrm{M}-1 \mathrm{~A}$ & $4-6 \mathrm{~A}$ & $10-14 \mathrm{~A}$ & $14 \mathrm{Jy}$ & Ovate & Sweet & Ovate & Sweet & Free & Yellow & Good & F-D & Malatya \\
\hline 8 & Hasanbey & $27-31 \mathrm{M}$ & $30 \mathrm{M}-3 \mathrm{~A}$ & $4-9 \mathrm{~A}$ & 13Jy & Oblong & Sweet & Oblong & Sweet & Free & Yellow & Good & F-D & Malatya \\
\hline 9 & İsmailağa & $24-30 \mathrm{M}$ & $28 \mathrm{M}-4 \mathrm{~A}$ & $3-9 \mathrm{~A}$ & $16 \mathrm{Jy}$ & Oblong & Sweet & Oblong & Sweet & Free & Yellow & Good & F-D & Malatya \\
\hline 10 & Kabaaşı & $18-26 \mathrm{M}$ & $23-30 \mathrm{M}$ & $27 \mathrm{M}-4 \mathrm{~A}$ & $13 \mathrm{Jy}$ & Ovate & Sweet & Ovate & Sweet & Free & Yellow & Good & $\mathrm{D}$ & Malatya \\
\hline 11 & Macar & $21-30 \mathrm{M}$ & $27 \mathrm{M}-4 \mathrm{~A}$ & $31 \mathrm{M}-9 \mathrm{~A}$ & $14 \mathrm{Jy}$ & - & - & - & - & - & - & - & F & Unknown \\
\hline 12 & M. Eriği & $30 \mathrm{M}-2 \mathrm{~A}$ & $3-5 \mathrm{~A}$ & $8-10 \mathrm{~A}$ & - & Ovate & - & Ovate & Sweet & Free & Yellow & - & F-D & Erzincan \\
\hline 13 & Mektep & $21-31 \mathrm{M}$ & $26 \mathrm{M}-2 \mathrm{~A}$ & $30 \mathrm{M}-6 \mathrm{~A}$ & 20Jy & - & - & - & - & - & - & - & F & İzmir \\
\hline 14 & Sakt-2 & $22-27 \mathrm{M}$ & $27-30 \mathrm{M}$ & $30 \mathrm{M}-4 \mathrm{~A}$ & 19Jy & Oblong & - & Ovate & Sweet & Free & Yellow & - & F & Hatay \\
\hline 15 & Saktt-6 & $21-31 \mathrm{M}$ & $28 \mathrm{M}-2 \mathrm{~A}$ & $31 \mathrm{M}-8 \mathrm{~A}$ & $18 \mathrm{Jy}$ & - & - & - & - & - & - & - & $\mathrm{F}$ & Hatay \\
\hline 16 & Saktt-7 & $23-28 \mathrm{M}$ & 29-31M & $1-8 \mathrm{~A}$ & 16Jy & - & - & - & - & - & - & - & $\mathrm{F}$ & Hatay \\
\hline 17 & Soğanc1 & $28-30 \mathrm{M}$ & $2 \mathrm{~A}$ & $5-7 \mathrm{~A}$ & - & Round & Sweet & Round & Sweet & Semi-Joint & Yellow & Good & D & Malatya \\
\hline 18 & Şekerpare & $22-28 \mathrm{M}$ & $30-31 \mathrm{M}$ & $3-4 \mathrm{~A}$ & $10-13 \mathrm{Jy}$ & Ovate & Sweet & Round & Sweet & Free & Yellow & Middle & $\mathrm{F}$ & Iğdır \\
\hline 19 & Tokaloğlu & $22-24 \mathrm{M}$ & $27-28 \mathrm{M}$ & $1-4 \mathrm{~A}$ & - & Ovate & Sweet & Elliptic & Sweet & Semi-Joint & Yellow & Soft & $\mathrm{F}$ & Erzincan \\
\hline 20 & Şahinbey & - & - & - & - & - & - & - & - & - & - & - & - & Mersin \\
\hline 21 & Çağrbey & - & - & - & - & - & - & - & - & - & - & - & - & Mersin \\
\hline 22 & Çağataybey & - & - & - & - & - & - & - & - & - & - & - & - & Mersin \\
\hline 23 & Dr. Kaşka & - & - & - & - & - & - & - & - & - & - & - & - & Mersin \\
\hline 24 & Alata Y1ldız1 & - & - & - & - & - & - & - & - & - & - & - & - & Mersin \\
\hline 25 & Aprikoz & $20 \mathrm{M}-1 \mathrm{~A}$ & $27 \mathrm{M}-3 \mathrm{~A}$ & $31 \mathrm{M}-3 \mathrm{~A}$ & - & Elliptic & Sweet & Oblong & Sweet & Free & Yellow & Middle & F & Iğdır \\
\hline 26 & Beliana* & $22-31 \mathrm{M}$ & $25-29 \mathrm{M}$ & $31 \mathrm{M}-4 \mathrm{~A}$ & $23 \mathrm{~J}$ & Round & Sweet & Round & Bitter & Free & Yellow & Good & F & Unknown \\
\hline 27 & Canino & $20-26 \mathrm{M}$ & $26-29 \mathrm{M}$ & $30 \mathrm{M}-5 \mathrm{~A}$ & $5 \mathrm{Jy}$ & Ovate & - & Ovate & Sweet & Semi-Joint & Orange & Soft & $\mathrm{F}$ & Spain \\
\hline 28 & Feriana* & $21-27 \mathrm{M}$ & $29 \mathrm{M}-1 \mathrm{~A}$ & $2-9 \mathrm{~A}$ & 30J-2Jy & Round & Sourish & Oblong & Bitter & Free & Yellow & Good & $\mathrm{F}$ & Unknown \\
\hline 29 & Fracasso & $18-29 \mathrm{M}$ & $22 \mathrm{M}-2 \mathrm{~A}$ & $28 \mathrm{M}-4 \mathrm{~A}$ & 16-17Jy & Round & Sweet & Ovate & Bitter & Joint & Yellow & Soft & $\mathrm{F}$ & Italia \\
\hline
\end{tabular}

M: March, A: April, J: June, Jy: July, F: Fresh, D: Dried. *These cultivars are derived from a Hamidi x Canino cross; Hamidi is a Tunisian cultivar. 


\section{DNA extraction}

DNA was extracted from young leaf tissue following the procedure described by Lefort et al. (1998). Concentration and purity of the DNA were determined with a NanoDrop ${ }^{\circledR}$ ND-1000 spectrophotometer.

\section{SSR analysis}

Eight SSR markers, namely UDAp-401 and UDAp-404 from apricot (Messina et al., 2004), UDP96-010, UDP96-019, UDP98-406 (Cipriani et al., 1999), Pchgms1, Pchgms2 and Pchgms3 from peach (Sosinski et al., 2000) were used in this study. Polymerase chain reactions (PCR) and SSR analysis were performed as previously described by Şelli et al. (2007). Briefly, PCR amplifications were performed in a reaction volume of $10-\mu \mathrm{L}$ reaction mixture containing $15 \mathrm{ng}$ DNA, 5 pmoL of each primer, $0.5 \mathrm{mM}$ dNTP, 0.5 unit GoTaq DNA Polymerase (Promega, Madison, WI, USA), including $1.5 \mathrm{mM} \mathrm{MgCl}$. The forward primers of each pair were labeled with WellRED fluorescent dyes D2 (black), D3 (green) and D4 (blue) (Proligo, Paris, France). The PCR conditions consisted of an initial cycle of 3 min at $94^{\circ} \mathrm{C}$, followed by 35 cycles of $1 \mathrm{~min}$ at $94^{\circ} \mathrm{C}, 1 \mathrm{~min}$ at $55-60^{\circ} \mathrm{C}$ and $2 \mathrm{~min}$ at $72^{\circ} \mathrm{C}$, with a final extension at $72^{\circ} \mathrm{C}$ for $10 \mathrm{~min}$. PCR products were diluted with sample loading solution, followed by the addition of Genomelab DNA Standard Kit-400 and electrophoresed in the CEQ 8800XL capillary DNA analysis system (Beckman Coulter, Fullerton, CA, USA). Allele sizes were determined for each SSR locus using the Beckman CEQ fragment analysis software. In each run, Canino was included as a reference cultivar. The analyses were repeated at least twice to ensure reproducibility of the results.

\section{Genetic analysis}

Number of alleles, allele frequency, expected (He) and observed heterozygosity (Ho), estimated frequency of null alleles, and probability of identity (PI) were calculated for each locus using the "IDENTITY" 1.0 program (Wagner and Sefc, 1999) according to Paetkau et al. (1995). The proportion of shared alleles was calculated using ps (option 1 - (ps)) as described by Bowcock et al. (1994) as genetic dissimilarity by the Microsat program (version 1.5) (Minch et al., 1995). These data were then converted to a similarity matrix, and a dendrogram was constructed with UPGMA (unweighted pair-group method with arithmetic mean) (Sneath and Sokal, 1973), using the NTSYS-pc software (Numerical Taxonomy and Multiware Analysis System) (version 2.0) (Rohlf, 1988).

\section{RESULTS}

Allele sizes (bp) generated by 8 SSR markers on 29 apricot cultivars are given in Table 2 . A total of 51 alleles were obtained by these 8 SSR markers. The number of alleles ranged from 4 (UDP98-406) to 10 (UDAp-404), with an average allele number of 6.37. The lowest and the highest He values were 0.392 and 0.839 for UDP96-019 and UDP96-010, respectively, with an average He value of 0.657 . The lowest Ho for UDAp-401 was 0.379 while the highest one was 0.896 for UDP96-010, with an average Ho value of 0.648 (Table 3). 


\begin{tabular}{|c|c|c|c|c|c|c|c|c|c|c|c|c|c|c|c|c|}
\hline \multirow{2}{*}{$\frac{\text { No. }}{1}$} & \multicolumn{2}{|c|}{ UDAp-401 } & \multicolumn{2}{|c|}{ UDAp-404 } & \multicolumn{2}{|c|}{ UDP96-010 } & \multicolumn{2}{|c|}{ UDP96-019 } & \multicolumn{2}{|c|}{ UDP98-406 } & \multicolumn{2}{|c|}{ Pchgms1 } & \multicolumn{2}{|c|}{ Pchgms2 } & \multicolumn{2}{|c|}{ Pchgms3 } \\
\hline & 205 & 205 & 150 & 158 & 84 & 94 & 165 & 165 & 88 & 88 & 160 & 166 & 145 & 145 & 193 & 195 \\
\hline 2 & 173 & 205 & 150 & 150 & 86 & 86 & 165 & 209 & 88 & 102 & 160 & 166 & 145 & 145 & 187 & 193 \\
\hline 3 & 213 & 213 & 152 & 158 & 80 & 86 & 165 & 209 & 84 & 88 & 166 & 170 & 151 & 173 & 191 & 195 \\
\hline 4 & 211 & 211 & 152 & 158 & 80 & 86 & 165 & 209 & 88 & 102 & 166 & 174 & 173 & 173 & 187 & 193 \\
\hline 5 & 173 & 205 & 150 & 150 & 84 & 86 & 165 & 209 & 88 & 102 & 160 & 166 & 145 & 145 & 187 & 193 \\
\hline 6 & 205 & 205 & 150 & 150 & 84 & 86 & 165 & 209 & 88 & 102 & 160 & 166 & 145 & 145 & 187 & 193 \\
\hline 7 & 173 & 215 & 158 & 158 & 80 & 80 & 165 & 209 & 98 & 102 & 170 & 174 & 159 & 173 & 193 & 195 \\
\hline 8 & 201 & 215 & 146 & 170 & 78 & 86 & 165 & 165 & 84 & 88 & 160 & 166 & 145 & 173 & 187 & 195 \\
\hline 9 & 215 & 215 & 180 & 182 & 86 & 94 & 165 & 165 & 102 & 102 & 166 & 174 & 173 & 173 & 187 & 195 \\
\hline 10 & 213 & 213 & 180 & 182 & 86 & 86 & 165 & 165 & 84 & 102 & 166 & 170 & 145 & 173 & 193 & 195 \\
\hline 11 & 173 & 205 & 148 & 150 & 84 & 86 & 165 & 209 & 88 & 102 & 160 & 166 & 145 & 145 & 187 & 193 \\
\hline 12 & 205 & 205 & 158 & 158 & 84 & 86 & 165 & 209 & 84 & 88 & 160 & 166 & 159 & 159 & 193 & 195 \\
\hline 13 & 205 & 205 & 158 & 170 & 94 & 98 & 165 & 165 & 88 & 88 & 160 & 160 & 145 & 159 & 187 & 195 \\
\hline 14 & 205 & 205 & 150 & 158 & 80 & 94 & 165 & 165 & 88 & 98 & 160 & 166 & 145 & 145 & 195 & 195 \\
\hline 15 & 205 & 205 & 158 & 158 & 98 & 100 & 165 & 165 & 88 & 98 & 166 & 166 & 145 & 145 & 193 & 195 \\
\hline 16 & 205 & 205 & 158 & 182 & 94 & 100 & 165 & 165 & 84 & 88 & 166 & 174 & 145 & 159 & 187 & 195 \\
\hline 17 & 213 & 213 & 158 & 182 & 86 & 98 & 165 & 185 & 88 & 98 & 160 & 170 & 159 & 173 & 195 & 195 \\
\hline 18 & 173 & 215 & 158 & 158 & 78 & 80 & 165 & 165 & 88 & 98 & 166 & 166 & 145 & 159 & 193 & 195 \\
\hline 19 & 173 & 205 & 158 & 158 & 84 & 94 & 165 & 165 & 84 & 88 & 160 & 174 & 159 & 171 & 195 & 195 \\
\hline 20 & 173 & 205 & 146 & 158 & 98 & 100 & 165 & 165 & 88 & 98 & 160 & 166 & 145 & 163 & 195 & 195 \\
\hline 21 & 205 & 205 & 146 & 158 & 78 & 80 & 165 & 165 & 88 & 98 & 166 & 168 & 145 & 163 & 195 & 195 \\
\hline 22 & 201 & 205 & 158 & 158 & 80 & 100 & 165 & 181 & 98 & 98 & 166 & 168 & 145 & 159 & 193 & 195 \\
\hline 23 & 171 & 201 & 146 & 182 & 80 & 84 & 181 & 209 & 88 & 98 & 160 & 166 & 159 & 163 & 193 & 195 \\
\hline 24 & 205 & 205 & 146 & 146 & 78 & 80 & 165 & 165 & 88 & 88 & 160 & 166 & 145 & 159 & 193 & 195 \\
\hline 25 & 205 & 205 & 158 & 158 & 94 & 98 & 165 & 209 & 88 & 88 & 160 & 170 & 145 & 159 & 193 & 195 \\
\hline 26 & 205 & 205 & 168 & 170 & 80 & 100 & 165 & 165 & 102 & 102 & 160 & 160 & 159 & 173 & 195 & 197 \\
\hline 27 & 205 & 213 & 146 & 156 & 80 & 96 & 165 & 189 & 88 & 88 & 166 & 166 & 145 & 147 & 195 & 195 \\
\hline 28 & 205 & 205 & 168 & 170 & 78 & 86 & 165 & 165 & 102 & 102 & 160 & 166 & 159 & 173 & 195 & 195 \\
\hline 29 & 205 & 205 & 158 & 158 & 94 & 100 & 165 & 165 & 88 & 88 & 166 & 174 & 145 & 173 & 193 & 195 \\
\hline
\end{tabular}

Table 3. Simple sequence repeat (SSR) loci, number of alleles (n), expected heterozygosity (He), observed heterozygosity (Ho), probability of identity (PI), and the frequency of null alleles (r) of 29 cultivars analyzed at 8 SSR markers.

\begin{tabular}{lcccrr}
\hline SSR locus & $\mathrm{N}$ & $\mathrm{He}$ & Ho & PI & \multicolumn{1}{c}{$\mathrm{r}$} \\
\hline UDAp-401 & 7 & 0.635 & 0.379 & 0.215 & 0.156 \\
UDAp-404 & 10 & 0.759 & 0.568 & 0.125 & -0.098 \\
UDP96-010 & 8 & 0.839 & 0.896 & 0.031 & -0.039 \\
UDP96-019 & 5 & 0.392 & 0.448 & 0.477 & -0.002 \\
UDP98-406 & 4 & 0.659 & 0.655 & 0.273 & 0.023 \\
Pchgms1 & 5 & 0.672 & 0.827 & 0.236 & -0.089 \\
Pchgms2 & 7 & 0.694 & 0.655 & 0.333 & \\
Pchgms3 & 5 & 0.613 & 0.758 & & \\
Total & 51 & 5.256 & 5.186 & & \\
Average & 6.37 & 0.657 & 0.648 & & \\
\hline
\end{tabular}

As far as the PI values are considered, the most informative loci were UDAp-404 (PI: 0.125 ) with 10 alleles and UDP96-010 (PI: 0.084) with 8 alleles. UDP96-019 (PI: 0.477) with 5 alleles was found to be the least informative locus (Table 3 ).

As for allele frequencies, the 165-bp allele at the UDP96-019 locus was the most frequently observed allele with a frequency of approximately $76 \%$. The least frequent loci (with a frequency of 1.7\%) were as follows: the 171-bp allele at the UDAp-401 locus, the 148- and 156-bp alleles at the UDAp-404 locus, the 96-bp allele at the UDP96-010 locus, the 191- and 
197-bp alleles at the UDP96-010 locus, and the 147-, 151- and 171-bp alleles at the Pchgms2 locus (Table 4).

Table 4. Allele frequencies of 8 simple sequence repeat loci.

\begin{tabular}{|c|c|c|c|c|c|c|c|c|c|c|c|c|c|c|c|c|}
\hline No. & UDAp-401 & alf & UDAp-404 & alf & UDP96-010 & alf & Pchgms3 & alf & UDP98-406 & alf & Pchgms 1 & alf & UDP96-019 & alf & Pchgms2 & alf \\
\hline 1 & 171 & 0.017 & 146 & 0.120 & 78 & 0.086 & 187 & 0.155 & 84 & 0.103 & 160 & 0.327 & 165 & 0.758 & 145 & 0.448 \\
\hline 2 & 173 & 0.120 & 148 & 0.017 & 80 & 0.206 & 191 & 0.017 & 88 & 0.500 & 166 & 0.448 & 181 & 0.034 & 147 & 0.017 \\
\hline 3 & 201 & 0.051 & 150 & 0.155 & 84 & 0.120 & 193 & 0.275 & 98 & 0.172 & 168 & 0.034 & 185 & 0.017 & 151 & 0.017 \\
\hline 4 & 205 & 0.568 & 152 & 0.034 & 86 & 0.241 & 195 & 0.534 & 102 & 0.224 & 170 & 0.086 & 189 & 0.017 & 159 & 0.241 \\
\hline 5 & 211 & 0.034 & 156 & 0.017 & 94 & 0.137 & 197 & 0.017 & & & 174 & 0.103 & 209 & 0.172 & 163 & 0.051 \\
\hline 6 & 213 & 0.120 & 158 & 0.431 & 96 & 0.017 & & & & & & & & & 171 & 0.017 \\
\hline 7 & 215 & 0.086 & 168 & 0.034 & 98 & 0.086 & & & & & & & & & 173 & 0.206 \\
\hline 8 & & & 170 & 0.068 & 100 & 0.103 & & & & & & & & & & \\
\hline 9 & & & 180 & 0.034 & & & & & & & & & & & & \\
\hline 10 & & & 182 & 0.066 & & & & & & & & & & & & \\
\hline
\end{tabular}

Genetic similarity of apricot genotypes ranged from 18 to $94 \%$. Native apricot cultivars in general showed a low level of similarity to exotic ones. Nevertheless, Fracasso, an Italian cultivar, clustered with the Turkish cultivar Sakit-6 (15). For exotic cultivars, the highest similarity (75\%) was found between Belina and Feriana, constituting a dual group in the dendrogram shown in Figure 1. In native genotypes, the highest similarity was found between Ethembey (5)-Hacıhaliloğlu (6), Ethembey (5)-Macar (11) and Ethembey (5)-Çekirge52 (2), with a genetic similarity of $94 \%$ (Figure 1 ).

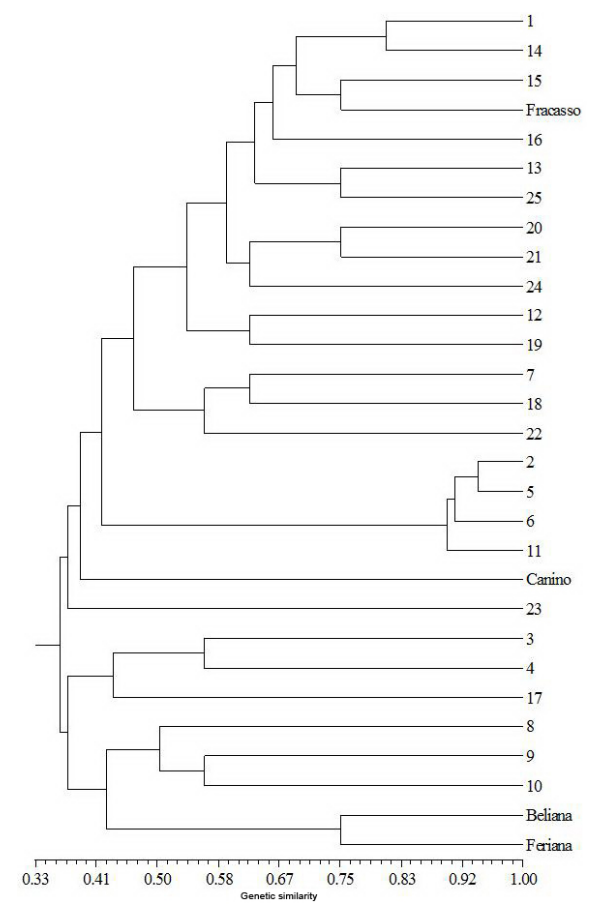

Figure 1. Genetic similarity (\%) dendrogram of apricot cultivars used in the present study. 


\section{DISCUSSION}

In this study, we were able to amplify DNA fragments from apricot using SSR markers, some of which have been previously developed for peach, another Prunus species (Cipriani et al., 1999; Sosinski et al., 2000). However, the average number of alleles detected in our study from apricot by these markers was different from peach. For example, Pchgms1, Pchgms2 and Pchgms 3 produced 4, 2 and 3 alleles, respectively, for peach (Sosinski et al., 2000), while only 2, 1 and 2 alleles, respectively, for cherry (Prunus avium L.) (Wünsch and Hormaza, 2002). In apricot genetic identification studies, the same loci (Pchgms1, Pchgms2 and Pchgms3) yielded 4, 5 and 3 alleles (Hormaza, 2002) while in the present study, the numbers of alleles revealed were 5, 7 and 5, respectively. These findings show that Pchgms1, Pchgms2 and Pchgms3 produced more alleles in apricot than in the other Prunus species. There is also evidence that Ho rates for these loci were higher in the present study than those found in earlier studies (Sosinski et al., 2000; Wünsch and Hormaza, 2002).

The SSR loci used in this study revealed higher heterozygosity rates in Turkish apricots than those in other Prunus species, including apricots from other regions of the world, suggesting that the apricot germplasm used in this study was probably more diverse (or heterozygous) than those used in other studies (Sosinski et al., 2000; Wünsch and Hormaza, 2002; Hormaza, 2002; Romero et al., 2003; Sánchez-Pérez et al., 2005). The high heterozygosity levels and allele numbers observed in the current study were particularly useful for efficient genetic identification of Turkish apricot germplasm. The high level of genetic identity (94\%) found between Ethembey (5) and Çekirge-52 (2), and between Ethembey (5) and Hacıhaliloğlu (6) also correlated well with several common pomological properties of these cultivars, such as taste, color and seed shape (Table 1).

The relatively high genetic similarity (75\%) between Çağrıbey (21; a Sakıt-6 x P. de Colomer cross) and Çağataybey (22; a Sakıt-2 x P. de Colomer cross) could be attributed to the fact that these two cultivars had the same pollinator (Batmaz, 2005). The relatively high similarity (75\%) between Beliana (a Hamidi x Canino cross) and Feriana (a Hamidi x Canino cross) could also be due to the fact that these cultivars had the same pollinator (Batmaz, 2005).

Sakit-2 (14), Sakit-6 (15) and Sakit-7 (16) were relatively less similar genetically and formed a homonymous group. It is interesting that Sakit-6 (15) and Sakit-7 (16) were also substantially similar to the exotic cultivar Fracasso, although no association between these cultivars has been previously reported.

The He values of UDAp-401, UDAp-404, UDP98-406, and Pchgms2 were higher than the Ho values. Previous reports by Zhebentyayeva et al. (2003) and Messina et al. (2004) also found relatively high He in some of these SSR loci in apricots. In this study, the frequency of null alleles at these four loci was positive, but these low values suggest the absence of null alleles (Table 3). Except for the above-mentioned apricot cultivars, in general, the genetic similarity among the cultivars was low and no synonymous cultivars were found, implying that Turkey is a rich source of diverse apricot germplasm. No correlation was found between the genetic relatedness and the geographical distributions of the cultivars.

Our findings reported here would be useful for better management of Turkish apri- 
cot germplasm. Notably, the data reported here could be directly compared to other studies, which have used or will be using the same SSR markers in other apricot genotypes or could be integrated into future studies investigating the genetic diversity of apricots from a broader geographical region.

\section{REFERENCES}

Anonymous (2003). TURKSTAT (State Institute of Statistics, Prime Ministry, and Republic of Turkey) official data. Agricultural Structure; Production, Price, Value, Ankara, Turkey.

Asma BM, Kan T and Birhanli O (2007). Characterization of promising apricot (Prunus armeniaca L.) genetic resources in Malatya, Turkey. Genet. Res. Crop Evol. 54: 205-212.

Badenes ML, Martínez-Calvo J and Llácer G (1998). Analysis of apricot germplasm from the European ecogeographical group. Euphytica 102: 93-99.

Batmaz MF (2005). Yield Quality of Some Apricot Cultivars in Adana Ecological Conditions (in Turkish, with English abstract). M.Sc. thesis, Çukurova University Science Institute, Adana.

Bowcock AM, Ruiz-Linares A, Tomfohrde J, Minch E, et al. (1994). High resolution of human evolutionary trees with polymorphic microsatellites. Nature 368: 455-457.

Cipriani G, Lot G, Huang WG, Marrazzo MT, et al. (1999). AC/GT and AG/CT microsatellite repeats in peach [Prunus persica (L.) Batsch]: isolation, characterisation and cross-species amplification in Prunus. Theor. Appl. Genet. 99: 65-72.

Geuna F, Toschi M and Bassi D (2003). The use of AFLP markers for cultivar identification in apricot. Plant Breed. 122: 526-531.

Hagen S, Khadari B, Lambert P and Audergon JM (2002). Genetic diversity in apricot revealed by AFLP markers: species and cultivar comparisons. Theor. Appl. Genet. 105: 298-305.

Hormaza JI (2002). Molecular characterization and similarity relationships among apricot (Prunus armeniaca L.) genotypes using simple sequence repeats. Theor. Appl. Genet. 104: 321-328.

Hormaza JI, Yamane H and Rodrigo J (2007). Apricot. In: Genome Mapping and Molecular Breeding in Plants (Fruits and Nuts) (Kole C, ed.). Springer-Verlag, Berlin, 171-187.

Hurtado MA, Westman A, Beck E, Abbott GA, et al. (2002). Genetic diversity in apricot cultivars based on AFLP markers. Euphytica 127: 297-301.

Lefort F, Lally M, Thompson D and Douglas GC (1998). Morphological traits, microsatellite fingerprinting and genetic relatedness of a stand of elite oaks ( $Q$. robur L.) at Tullynally, Ireland. Silvae Genet. 47: 257-262.

Maghuly F, Fernandez EB, Ruthner S, Pedryc A, et al. (2005). Microsatellite variability in apricots (Prunus armeniaca L.) reflects their geographic origin and breeding history. Tree Genet. Genomes 1: 151-165.

Mariniello L, Sommella MG, Sorrentino A, Forlani M, et al. (2002). Identification of Prunus armeniaca cultivars by RAPD and SCAR markers. Biotechnol. Lett. 24: 749-755.

Messina R, Lain O, Marrazzo MT, Cipriani G, et al. (2004). New set of microsatellite loci isolated in apricot. Mol. Ecol. Notes 4: 432-434.

Minch E, Ruiz-Linares A, Goldstein DB, Feldman M, et al. (1995). Microsat (Version 1.4d): a Computer Program for Calculating Various Statistics on Microsatellite Allele Data. University of Stanford, Stanford.

Özbek S (1978). Özel Meyvecilik (Kisin Yapragini Döken Meyve Türleri). Publications No.: 128, Textbook No.: 11. Çukurova University Agricultural Faculty, Adana.

Paetkau D, Calvert W, Stirling I and Strobeck C (1995). Microsatellite analysis of population structure in Canadian polar bears. Mol. Ecol. 4: 347-354.

Pedryc A, Ruthner S, Herman R, Krska B, et al. (2009). Genetic diversity of apricot revealed by a set of SSR markers from linkage group G1. Sci. Horticul. 121: 19-26.

Rohlf F (1988). NTSYS-PC Numerical Taxonomy and Multivariate Analysis System. Version 2.0. Exeter Publishing Ltd., Setoukat.

Romero C, Pedryc A, Munoz V, Llacer G, et al. (2003). Genetic diversity of different apricot geographical groups determined by SSR markers. Genome 46: 244-252.

Sánchez-Pérez R, Ruiz D, Dicenta F, Egea J, et al. (2005). Application of simple sequence repeat (SSR) markers in apricot breeding: molecular characterization, protection, and genetic relationships. Sci. Horticul. 103: 305-315.

Şelli F, Bakir M, Inan G, Aygün H, et al. (2007). Simple sequence repeat-based assessment of genetic diversity in 'Dimrit' and 'Gemre' grapevine accessions from Turkey. Vitis J. Grapevine Res. 46: 182-187. 
Sneath PHA and Sokal RR (1973). Numerical Taxanomy. Freeman, San Francisco.

Sosinski B, Gannavarapu M, Hager LD, Beck LE, et al. (2000). Characterization of microsatellite markers in peach [Prunus persica (L.) Batsch]. Theor. Appl. Genet. 101: 421-428.

Wagner HW and Sefc KM (1999). IDENTITY 1.0. Freeware Program for the Analysis of Microsatellite Data. Centre for Applied Genetics, University of Agricultural Science, Vienna.

Wünsch A and Hormaza JI (2002). Molecular characterisation of sweet cherry (Prunus avium L.) genotypes using peach [Prunus persica (L.) Batsch] SSR sequences. Heredity 89: 56-63.

Zhebentyayeva TN, Reighard GL, Gorina VM and Abbott AG (2003). Simple sequence repeat (SSR) analysis for assessment of genetic variability in apricot germplasm. Theor. Appl. Genet. 106: 435-444. 